\title{
TONO-BUNGAY AND BURROUGHS WELLCOME: BRANDING IMPERIAL POPULAR MEDICINE
}

\author{
By Meegan Kennedy
}

H. G. WELLS'S 1908 NOVEL TONO-BUNGAY ${ }^{1}$ is a remarkable concoction, binding together characters and setting out of Dickens, sparkling imitations of fin-de-siécle commodity culture and new media, bitter social satire inflected by Wells's socialism, fascination with invention and flight, and murderous imperial adventure. Readers, though often seduced by the wit and precision of Wells's depiction of patent medicines and their advertisements, have not known whether to read the narrative as anti-Bildungsroman, Condition of England novel, science fiction, or imperial romance. It is no wonder that many critics have labeled this novel a failure.

The novel, which Wells had labored over for two years, presents itself as the memoir of George Ponderevo, beginning with his childhood and taking on energy as he chronicles the rise and fall of his uncle's patent medicine firm and his fortune. The novel provides a dizzying tour of the interconnected markets in domestic consumables and the mental "consumables" of mass media, from advertisements to periodicals. It moves from London to a remote tropical island, in a reminder that not all the significant exchanges in late-nineteenth-century consumer culture are confined to the gendered space of the urban department store. That the novel's capitalism is imperial is revealed in the unexpected departure of the protagonist from the metropolis to a little-known African island to collect a mysterious radioactive material known as "quap." This episode, long condemned by critics as inartistic, has recently been embraced for its reminder of the interconnected economics and dynamics of global capitalism, although the shift from London to Africa and from medicine to raw resource is still jarring.

However, the worlds of popular medicine and imperial adventure travel are not as disparate as they seem, as we can see in a closer examination of the antecedents and reach of late-Victorian patent and proprietary medicine brands. Wells writes, in his "Preface to Volume XII of the Atlantic Edition" of the novel, that his plan "was to give a view of the contemporary social and political system in Great Britain, an old and degenerating system, tried and strained by new inventions and new ideas and invaded by a growing multitude of mere adventurers." 2 Although in this context Wells likely uses the term "adventurers" to refer to bounders like his character Edward Ponderevo, late-Victorian culture also affiliated certain popular medicines, particularly Burroughs Wellcome's phenomenally successful "Tabloid" brand products, with the bold exploits of explorers like Henry Stanley, who had been accused 
of being, as he bitterly put it, "a buccaneer, an adventurer, a fraud, and an imposter!" (Stanley, Autobiography 528).

Scholarship on Tono-Bungay has addressed its genre and its critiques of capitalism and imperialism but has said comparatively little about its fascination with popular medicine and advertising. We might accept the brand "Tono-Bungay" as simply a convenient example of the domestic consumables flooding the advertising space and a useful way for the socialist Wells to interrogate medical and financial authority. But Wells's choice of commodity also affords a unique relation to the imperial capitalism he critiques in the novel. Patent medicines (so-called "quack" medicines) and their itinerant vendors are an easy target for satire; but "Tono-Bungay" demonstrates a clearer (and not less cutting) resemblance to the proprietary medicines produced by a large international pharmaceutical firm. The novel thus sketches a portrait of a more global and more apparently respectable form of capitalism, of equivocal character, when it was undergoing remarkable expansion along imperial lines. This essay argues that the pharmaceutical firm Burroughs Wellcome and its "Tabloid" brand products, deeply entangled as these are with innovations in advertising and with imperial expeditions, usefully illuminate the hidden structures of the novel, in particular the vexing "quap" episode. "Tabloids" show up the conceptual bonds that link several disparate concerns of the novel, namely the "branding" and commodity culture of imperial capitalism, the inventive mobility of these commodities as they travel globally, and Wells's reflections on what this means for the political, economic, and cultural conditions of England. As a result, I argue, the "Tabloid" brand helps us see why Wells revises the genre of the novel as he does. Although it begins traditionally enough with descriptions of feudal England and the country house set against questions of industrial capitalism and labor relations, the second half of the novel explodes away from the conventional plot toward an imperial adventure, much as Uncle Edward rockets metaphorically skyward in George's account of the rise of his business. All uncle, business, and plot - are propelled by Tono-Bungay. The "Tabloid" brand of Burroughs Wellcome, which may even be a model for Tono-Bungay, demonstrates the globalization of capital at the turn of the century and suggests why, by 1908, the momentum of the "Condition of England" novel must now travel, ultimately, to imperial romance instead.

\section{Wells and Popular Medicine}

THE SPECIFIC THAT THE NOVEL presents, called Tono-Bungay, is a proprietary medicine, a form of commodity that Wells knew well. In his 1934 Experiment in Autobiography, he recalls the month he spent training in the shop of an energetic pharmaceutical chemist named Cowap (perhaps a homonym for "quap") in 1881. This brief apprenticeship provided much of the detail of Uncle Edward's shop - the white (plaster of Paris) horse to indicate veterinary remedies, the bottles of colored water, the soda-water siphons, the cough linctus, the rolled pills, the rows of drawers, the gilt labels, and of course the patent and proprietary medicines (Wells, Experiment 107) (Figure 4). ${ }^{3}$ Indeed, Simon James argues that "[p]atent medicines and advertising were clearly obsessions for Wells" (112, fn 114). Although George, the narrator, is the protagonist of the novel, he is rivaled in that status (and in his uncle's affections) by Tono-Bungay itself, as the novel chronicles the growth, maturity, and fall of the product as much as of the man.

Medicine was ideally suited to serve as a kind of protagonist for a novel fascinated by advertising. During the late Victorian period, although other domestic consumables like soap 


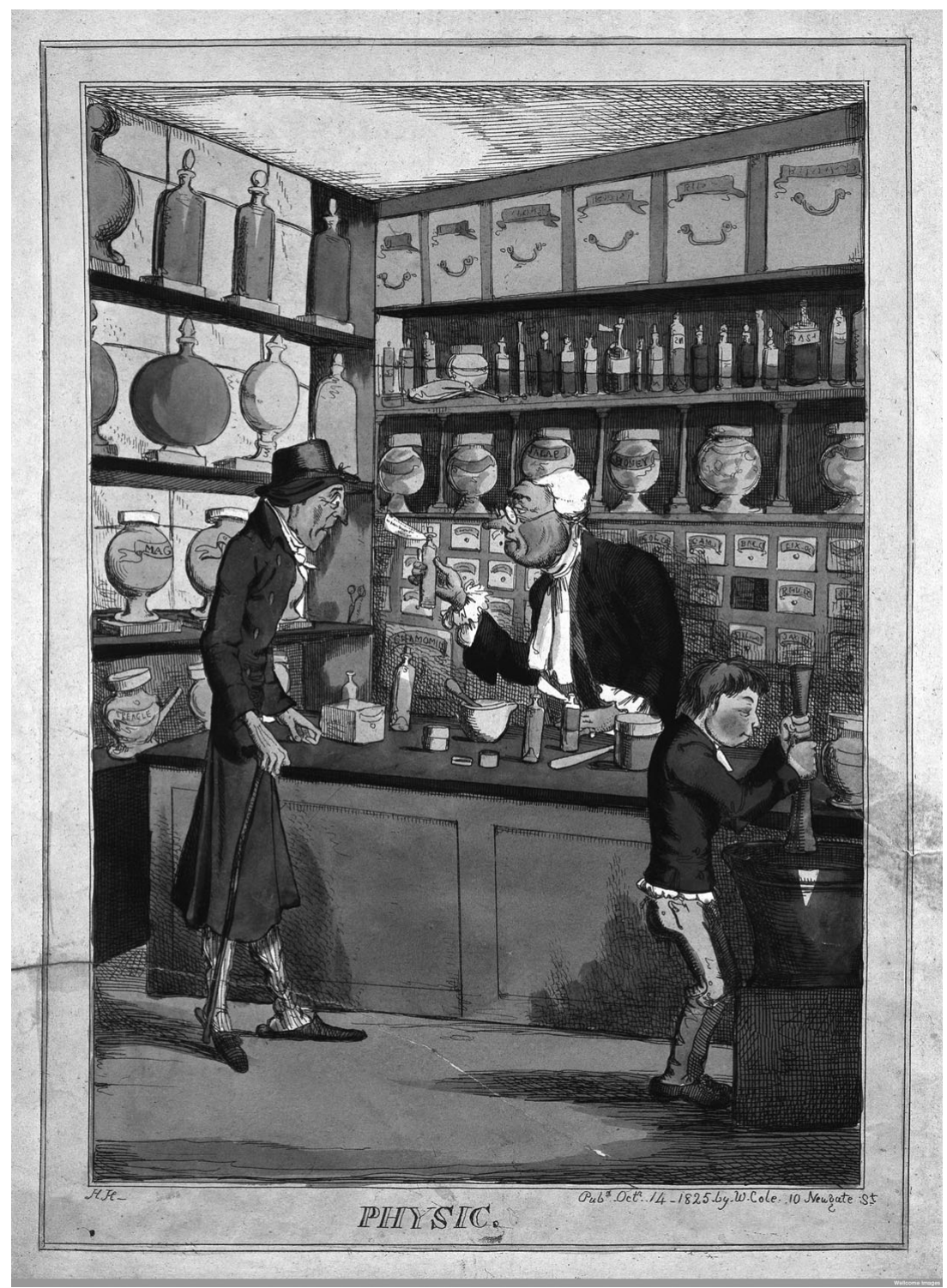

Figure 4. Interior of a nineteenth-century pharmacy. Colored etching by H. Heath, 1825. Wellcome Library, London (M0018898).

(a product also featured in the novel) were heavily advertised, medicine manufacturers were known for their expansion of advertising in both method and extent (Young 39-43). ${ }^{4}$ Such manufacturers bought more advertising than any other type of vendor (Nevett 71). Either the medicines or the barrage of advertising must have worked, for such products enjoyed 
unprecedented success during this period; patent medicine purchases were nearly nine times greater in 1913 than they had been in 1853 (Corley 38).

The firm of Tono-Bungay presents a complex hybrid of qualities associated with popular medicine. British medicine became both more professional and more commercial in the late nineteenth century; British popular medicine followed suit. People could access a diverse range of treatments, some mediated by a physician, surgeon, or apothecary, others perhaps guided by a text like William Buchan's much-reprinted Domestic Medicine or a local resource. But increasingly patients turned not just to homegrown or locally-made remedies but commercial remedies that one could purchase over the counter, through the mail, or from a local chemist or itinerant salesman. ${ }^{5}$

Among these, many scholars distinguish between patent and proprietary medicines. Patent medicines were more likely to be "cure-alls," to be sold by itinerant vendors and peripatetic quack doctors with sensational claims, and to shroud their supposedly exotic ingredients in secrecy. They participated in a long tradition of sectarian medicines often founded on old folk remedies and dismissed by many as "quackery." Some were less harmful or more efficacious than treatments used by "regular" (allopathic) physicians, especially in the earlier part of the century when so-called "heroic" treatments still dominated regular medicine despite their harsh side effects and little curative value (Helfand 32). However, while some patent medicines contained active ingredients that could alleviate minor ills like headache or indigestion, often they proved worthless or harmful despite their outrageous claims. Even when they had active ingredients, these were usually worth only a tiny fraction of the cost charged. Ironically, such products, frequently just repackagings of domestic recipes, were rarely actually patented (Schupbach 297). Patent medicines drew the ire of physicians; consumers would buy patent remedies from a traveling salesman instead of seeing a doctor for their symptoms.

Proprietary medicines, which emerged as a category later in the nineteenth century, could be used by medical practitioners as an easy way to prescribe a simple remedy such as the traditional "Blaud pill" (iron supplement). Based on standard or patented formulae (and thus also "patent" medicines of a kind), these were manufactured and sold by respectable pharmaceutical firms, some of which are still in existence. However, in the later years of the century, druggists and proprietary medicine vendors faced a more competitive market (Corley 104-05; Church and Tansey 130ff; Ueyama 33-38). Both patent and proprietary medicines aggressively pursued trade, and the lines between them were not always clear (Church 378). ${ }^{6}$ Despite their differences, many patent and proprietary medicines could alike be acquired at the local druggist's without a doctor's intervention; both types of popular medicine drew heavily on the power of the brand name and on innovative advertising and marketing techniques to draw the mass consumer; and both still could rely on secret ingredients. However, proprietary medicines enjoyed more credibility than patent medicines and anchored some of the largest serious pharmaceutical firms of the twentieth century. Beecham's Pills, for example, developed into multinational giant SmithKline Beecham (currently GlaxoSmithKline).

\section{Patent Medicines}

WELLS'S INTEREST IN A PRODUCT LIKE TONO-BUNGAY as the vehicle for his critique of corporate capitalism may reflect the prominence of patent and proprietary medicines in the 
news during the years leading up to the publication of the novel. In 1907, in an effort to expose the fraudulence of many patent medicines, the British Medical Association began publishing exposures of "Secret Remedies," e.g., patent medicines foisted on the public with claims of mysterious ingredients and curative prowess. Using chemical analysis, the BMA demonstrated the cheap and often inactive ingredients in most of these tonics, powders, and pills. The 1909 volume reprint of this series sold briskly and inspired a sequel, More Secret Remedies, in 1912. Such skeptical publications were equally necessary across the Atlantic, where the American Medical Association had publicized a similar set of studies, and Ladies' Home Journal and Collier's had published series attacking deceptive nostrums over the previous decade.

Scholars are mixed in their assessment of these exposés. Peter Bartrip argues that the BMA's series of articles and two books did not add much to what lay and professional media had already been discussing; for example, George Simmons of the Journal of the American Medical Association took the British Medical Journal to task for continuing to accept advertising from some proprietary medicines with secret formulae, even as the BMA postured against these remedies in the pages of the journal. And of course these associations' attacks on secret nostrums likely diverted some consumers' money away from popular medicines and back to more conventional medical practitioners; Takahiro Ueyama meticulously details the capitalist pressures behind the physicians' efforts to regulate patent medicines (24-58). But there is no doubt that the series in the $B M J$, republished in volume form, brought public attention to the problem of patent and proprietary medicines during the years immediately preceding Wells's publication of Tono-Bungay, so that the novel, appearing just before the volume edition of Secret Remedies, was in essence commenting on current events.

Tono-Bungay is a "secret remedy" of the sort that was attracting adverse attention during the years when Wells was writing the novel. Although Uncle Edward tells George the ingredients, Wells has George keep the formula secret from readers because "Tono-Bungay is still a marketable commodity" (140; bk. 2 , ch. 2$)$, thus presenting a façade of authenticity by pretending the text is documentary rather than fiction, in the tradition of nineteenth-century romances. But we get a sketch of the concoction:

\footnotetext{
"You see," said my uncle in a slow confidential whisper... "it's nice because of the" (here he mentioned a flavouring matter and an aromatic spirit), "it's stimulating because of" (here he mentioned two very vivid tonics, one with a marked action on the kidneys). "And the" (here he mentioned two other ingredients) "makes it pretty intoxicating. Cocks their tails. Then there's (but I touch on the essential secret). "And there you are. I got it out of an old book of recipes - all except the" (here he mentioned the more virulent substance, the one that assails the kidneys), "which is my idea. Modern touch! There you are!"' (140-41; bk. 2, ch. 2)
}

Tono-Bungay thus includes typical ingredients of its kind: two tonics, one of which is likely to be caffeine (with its pronounced diuretic effect); two intoxicants (certainly alcohol and perhaps cocaine, which was not uncommon in patent medicines of the day); a flavoring (an extract such as vanilla, anise, or lemon); an aromatic spirit (aromatic spirit of ammonia containing ammonia, alcohol, distilled water, and aromatic oils of lemon, lavender, and nutmeg - was used as a stimulant, an antacid, and a flatulence remedy); and some essential secret ingredient (perhaps a strongly-flavored spice like cloves). 
Some commentators have noted that Tono-Bungay has much in common with the original Coca-Cola. Edward Mendelson argues that "almost every detail of the ingredients and history of Tono-Bungay is based on Coca-Cola, which Wells probably learned about during his visit to the United States in 1906" (xxiii). The American beverage Coca-Cola was developed as an offshoot of the tonic called "Pemberton's French Wine Coca," a mixture using the kola nut for caffeine (a tonic), Peruvian coca, and wine (two intoxicants). John Pemberton reformulated the blend in 1886 when Atlanta restrictions on spirituous liquors forced him to revise the recipe, adding sugar and flavorings to replace the alcohol.

Tono-Bungay does show significant similarities to Coca-Cola, and Wells may well have seen coverage of the controversy over it as a "secret remedy" in 1902. ${ }^{7}$ However, the composition of Tono-Bungay does not differ substantially from many other British "secret remedies" of the sort exposed by the BMA. Even respectable and widely used concoctions relied on ingredients we would now consider suspect. Vin Mariani, for example, found tremendous success with its original formula blending two intoxicants, coca and alcohol.

\section{Patent Medicine Sellers: Sequah}

IF TONO-BUNGAY SHARES INGREDIENTS with many of its real-life peers, its inventor does also. Uncle Edward shares a number of parallels with the purveyors of patent medicines, including a larger-than-life, Dickensian exuberance. One such character well-known in Britain from 1887 through 1895, for example, was William Hartley, who became renowned as "Sequah," the befringed "Indian" persona he adopted to peddle the "Sequah" patent medicines. Despite the brand's ostensible allusion to Native American traditional cures, which Hartley dramatized in his apparel and his stories about the West, the Sequah products were composed largely of ordinary ingredients like oil, turpentine, soda, alcohol, aloes, and pepper (Schupbach 276). Hartley himself was merely a native of Yorkshire with a flair for the dramatic.

William Schupbach has noted the resemblances between Hartley and Edward. ${ }^{8}$ Like many patent medicine sellers, Hartley made good use of newspaper advertisements and the free advertising provided by local news articles. His advertising style, with rows of "triplets" (all-caps pronouncements repeated in stacks of three), was so distinctive that Sequah advertisements were even parodied (Schupbach 290). ${ }^{9}$ Hartley even turned newspaper publisher as a vehicle for his products: the Sequah Chronicle, a weekly paper, published "short stories, essays, and jokes... advertisements and the more favourable accounts of Sequah culled from local newspapers" (Schupbach 280). Edward, of course, also relies heavily on newspaper advertisements and buys the Sacred Grove to assist him in covering the market. Similarly, both Hartley and Edward "made and lost a huge fortune" through the marketing of their branded products. As with Edward's Tono-Bungay and respectable real-life firms like Boots, Hartley's products were so successful that he eventually took his company public (Schupbach 292). Both Hartley and Edward win and then lose immense wealth by peddling worthless tonics.

Hartley's Sequah does show striking parallels to Tono-Bungay and illustrate the context of patent medicine that Wells was critiquing by portraying Tono-Bungay as a worthless stimulant. However, it may be equally useful to consider their points of divergence: Hartley began as an itinerant medicine man, thriving on spectacle, drawing teeth in front of huge crowds. Edward, on the other hand, starts as a bourgeois chemist running a quiet (too quiet!) 
little shop. Presumably he is conventionally trained and registered. Furthermore, unlike Hartley, Edward is not flamboyant. He doesn't perform, himself: it is Tono-Bungay that is performed, in the advertisements. And while Edward does become larger-than-life - one of the conceits of the novel is that Edward physically inflates with success - he becomes known as the man behind Tono-Bungay, not as its eponymous incarnation. If he plays any role, it is that of business tycoon. It is perhaps for this reason that, unlike Hartley, Edward does not recruit and train substitutes for himself. Hartley developed a stable of "Sequahs," mostly other tooth-pullers or traveling salesmen of patent medicines, to carry on performances in multiple cities at once; he ran twenty-three "Sequahs" in September 1890 (Schupbach 286). But Edward's role cannot be multiplied.

Perhaps the most illuminating difference between the medicaments Sequah and TonoBungay (or the personae of Sequah and Uncle Edward) is that Wells is parodying not the effronteries of an itinerant quack but the piracies of a respectable capitalist. Sequah was always operating on the unsavory fringes of medicine; he was refused the rental of meeting halls and relegated to whatever vacant land might be available and large enough to hold his unruly crowds. The history of the Sequah brand is littered with mountebanks, scoundrels, drunkards, and thieves. Hartley's greed and effrontery - even defrauding his employees was if anything magnified by the motley group of "Sequahs" and their assistants, many of whom proved more than his equal in their tendencies to drama, violence, plagiarism, fraud, and theft (Schupbach 310). In contrast, Edward moves in the highest circles, albeit uneasily, and his story reveals the crimes of the great. In this regard, Edward is more like Whitaker Wright, the fraudulent financier whose fall in 1904 may have inspired the novel, or John Morgan Richards, the American patent-medicine seller who introduced a number of popular medicaments (including Carter's Little Liver Pills and Dr. Williams's Pink Pills for Pale People) into England (Mendelson xxiii). Richards, like Edward, achieved tremendous social success, even buying an old castle and writing a book about it. ${ }^{10}$

\section{Proprietary Medicines: Burroughs Wellcome and the "Tabloid" Brand}

WELLS ROBUSTLY SKEWERS THE extravagant claims and material sham of patent medicines, but the novel also lambasts another form of popular treatment, proprietary medicines. In fact, while Tono-Bungay has important parallels to patent medicines, it has equally important links to their more respectable cousins. One significant analogue to Tono-Bungay may be the "Tabloid" brand proprietary medicines sold by the British manufacturing chemists Burroughs Wellcome, currently folded (with Beecham's Pills) into the pharmaceutical giant GlaxoSmithKline.

Indeed, Uncle Edward's precipitous success may reflect not only the context of American tonics like Coca-Cola but also the extraordinary growth of firms like Burroughs Wellcome during the years immediately preceding the novel's publication. Silas Burroughs and Henry Wellcome, with degrees from the Philadelphia College of Pharmacy, began their careers as pharmaceutical salesmen. Burroughs had been the sole representative in Britain selling Wyeth's compressed pills (standardized, mass-produced tablets made by mechanically compressing loose powder ingredients). These offered a number of advantages over the usual forms of medicine: they were small, light, and tasteless, unlike liquid medicines or powders; they were chemically stable and resisted the influence of climate; and, unlike compounded medicines or hand-rolled pills, each dose contained an exact, standardized 
amount of the pure, active ingredients of the medicine, doing away with the need to weigh or measure and obviating under- or over-dosages and waste. Burroughs invited Wellcome to join him in a new venture in 1880 , founding a pharmaceutical company that, at first, was a vendor of other people's patent and proprietary medicines, and then, in 1884, registered the trademark "Tabloid" to describe its mechanically-produced, compressed pills, using the American technology. This allowed the firm to begin developing its own proprietary medicines, many marketed under the "Tabloid" name. The term was always printed within quotation marks, perhaps at first because it was a coinage, later probably to indicate its status as a brand name.

These men, then, demonstrate marketing genius more than scientific discovery; they leverage existing products into new markets using new technologies in manufacturing and in media. George (the narrator) refines the manufacturing process of Tono-Bungay, just as Burroughs and Wellcome were not inventors as much as expanders upon the compression technology. Edward and Wellcome are chemists (pharmacists) purveying popular medicines, who do not discover a new product as much as cannily market a new product or process already available. ${ }^{11}$

Like Edward, Burroughs and Wellcome did not start out in the "educated, even distinguished, elite fraternity" of chemical firms respected by the medical establishment (Church 379). As Americans and traveling representatives even of a respectable firm, Burroughs and Wellcome were associated with the more déclassé aspects of American trade in popular medicine. Like Edward, they parlayed their pharmacy degree and experience into a tremendous business success by combining expertise with novelty. Like Edward, Henry Wellcome took on an utterly modern role as assertive leader of a powerful new firm with global reach when after Burroughs's death in 1895 he took over sole ownership of the company. And like Edward and a number of other late-Victorian businessmen, Wellcome rose from modest - but respectable and conventionally trained - origins to a social pinnacle.

\section{Expansion}

LATE-NINETEENTH-CENTURY FIRMS, faced with an increasingly competitive marketplace, sought to expand their product line from medicines into other domestic consumables. Both Burroughs Wellcome and Edward drew on the market success of their signature brand to expand into a range of products marketed under that singular name.

Burroughs Wellcome extended their "Tabloid" brand to remarkable ends, so that the brand encompassed everything from powerful medicines like strychnine or digitalis to milder or even non-medicinal products. By the 1890s there were over one hundred types of "Tabloid" products on the market (Church and Tansey 49). By 1907, the list of "Tabloids" spans thirty pages of small print. The firm offered "Pepsin Tabloids," "Quinine Tabloids," "Saccharine Tabloids," "Voice Tabloids," "Tabloid Soda-Mint," "Tabloid Thirst-Quencher," and "Tabloid Pastilles," among others (Anaesthetics 146-77) 12 (Figure 5). Their "Tabloid" brand medicine chests, filled with - of course - "Tabloids," had a distinct relation to their core business. Their "Tabloid" photographic supplies, from 1893, were also in tabloid form. Finally, "Tabloid" tea spread the potent brand name to other kinds of familiar household consumables. Especially significant for our reading of Tono-Bungay, in 1890, Burroughs Wellcome introduced the "Tabloid Forced March," 13 tablets that - like Coca-Cola and probably Tono-Bungay contained kola and coca. A 1906 listing for “"Tabloid' 'Forced March”" boasts that "it allays 


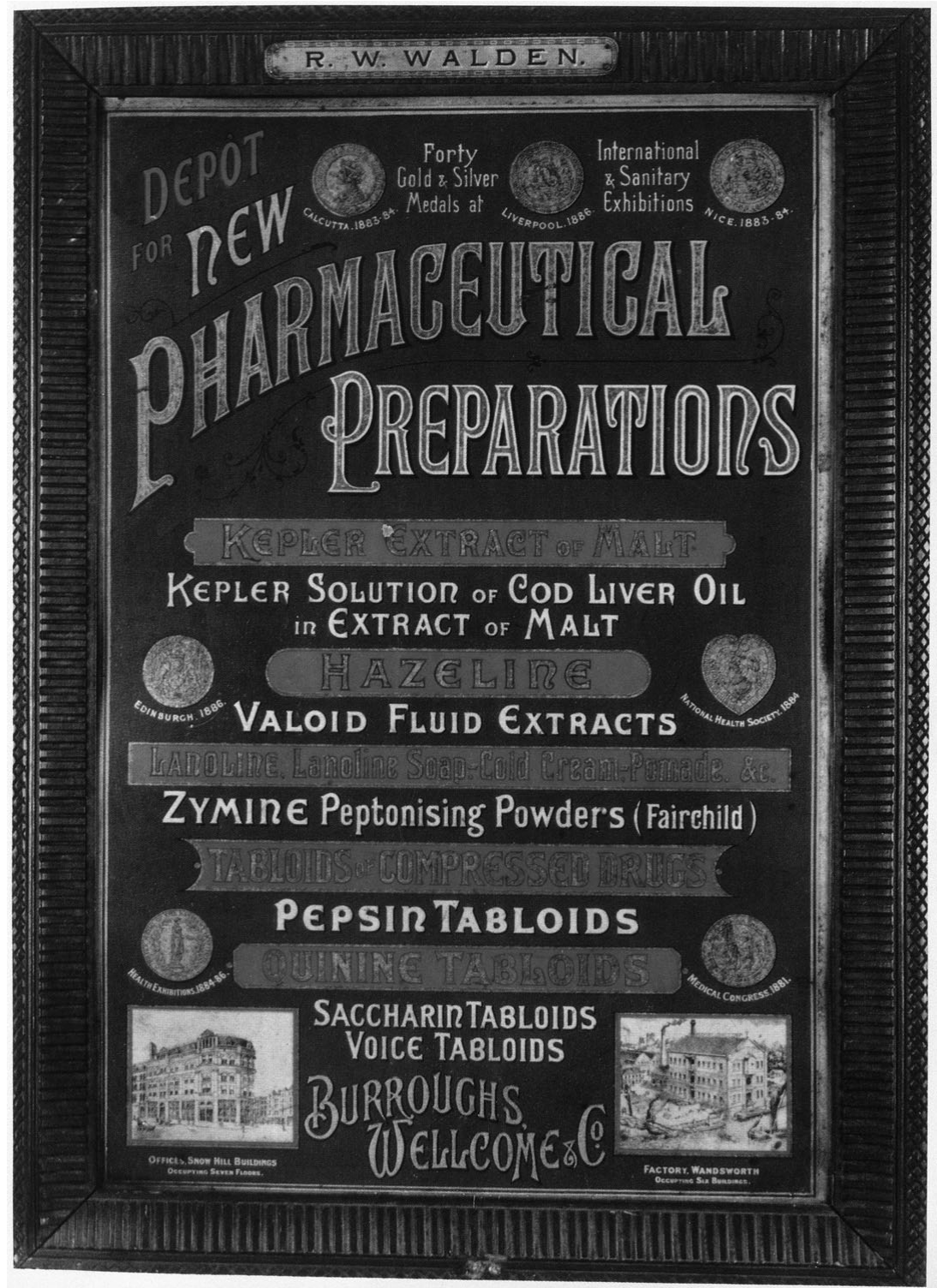

Figure 5. Pharmaceutical sign advertising Burroughs Wellcome products, including "Tabloid" brand products, c. 1885. Wellcome Library, London (L0025818).

hunger, and prolongs the power of endurance in those undergoing severe mental strain or physical exertion, especially when deprived of food" (Burroughs Wellcome, "Abridged List" 47). This compound stood with "Tabloid" Voice, another cocaine-containing product, which was marketed to singers, barristers, and clergymen. 
In the novel, the expansion is similarly framed as a seemingly natural growth of Edward's first success. Like Wellcome, he extends the familiar brand into other consumables when he expands into "Tono-Bungay Hair Stimulant," "Concentrated Tono-Bungay" ("for the eyes"), and Tono-Bungay lozenges, chocolate, and mouthwash. However, the novel's satire undercuts these peculiar pairings (hair lotion and chocolate?); at least "Tabloid" brand tea and soda-mint were actually in tabloid (compressed tablet) form. Edward suggests the possibility of a Tono-Bungay sea-sickness remedy, but George nixes it as difficult to advertise (162-63; bk. 2, ch. 3). Perhaps he is beginning to feel a little queasy about their methods.

Many patent and proprietary medicine vendors drew on their business success to underwrite new ventures outside medicine proper. Hartley launched an expansion when his core business, Sequah, was threatened by new legislation outlawing itinerant medicineselling; he opened the short-lived Dinah Blacking and Polish Company in 1891 (Schupbach 306, 312). Burroughs Wellcome diversified production early on to include a range of products with catchy invented names: Soloid (for solubles), Vaporole (inhalants), Lanoline (lanolin products, from sheep's wool), Hazeline (from witch hazel). These last, which were cosmetic products, were advertised more widely than the medical products. Burroughs Wellcome also expanded its pharmaceutical warrant to include not only related products like cosmetics and creams but also general household consumables. ${ }^{14}$ The firm considered expanding its popular "Hazeline" face cream (also marketed for hair loss) into related products like soap, shaving cream, veterinary products, and even toilet paper. Even before "Tabloids" it had acted as distributor for Nubian Waterproof Blacking (Church 380). While Hartley started a new brand name and company for his move into domestic cleaning products, Burroughs Wellcome extended its original brand name well beyond its original purview, in this case, broadening the "Tabloid" brand from proprietary medicines to other tabloid-format products - first aid kits and photographic supplies - also procured from chemists. Wells similarly dramatizes the chronological and metaphorical momentum of a powerful branded product when, fueled by the rapid success of Tono-Bungay, Edward takes on "Moggs' Domestic Soap" and expands it to include "a plate powder, 'the Paragon,' and a knife powder" along with "a good little second-rate black-lead firm" (227, 230). Wells demonstrates a keen eye for the domestic consumables likely to be linked with patent or proprietary medicine when Uncle Edward takes on soap and blacking.

\section{Science in the Popular Medicine Business}

AS PATENT AND PROPRIETARY MEDICINES were more closely scrutinized and regulated over the course of the nineteenth century, proprietary medicines sought to differentiate themselves as more scientific. Both real and fictional firms draw upon the cultural authority of science rather than emphasizing the popular elements of their products; they frame their remedies not as demotic but as elite. Burroughs and Wellcome worked to build their firm's association with scientific medicine. For example, they pioneered the practice of sending well-informed representatives to meet individually with doctors in their offices (Rhodes James 102; Beckett 109). Wellcome turned to science not only because, as a businessman and marketer, he knew it would enhance his product's credibility, but also to ensure consistently high quality in his products. ${ }^{15}$ The firm's chemical and physiological laboratories earned a number of honors in international exhibitions and were declared to be independent of the business end of the 
organization (Burroughs Wellcome, "Wellcome's Medical Diary and Visiting List 1907," endpapers).

Although Victorian novels (such as The Woman in White or Dr. Jekyll and Mr. Hyde) sometimes portray chemists as sinister villains, chemistry was invaluable in the vigorous campaign against adulterated food at mid-century, and the general public would have associated this study with the purity, safety, and efficacy of consumed goods. Thus Uncle Edward is canny to play up his role as chemist. His Tono-Bungay offices advertise a scientific business behind the "Temporary Laboratory" by means of "a crowded suggestion of crucibles and glass retorts and... air-pump... [and] the electrical machine... evidently placed on a shelf just at the level to show," seen dimly through a glass transom (138; bk. 2, ch. 2). These props deceptively present Uncle Edward as not just a druggist but a working experimental chemist. Burroughs Wellcome also took pains to develop an association with chemists and pharmaceutical research rather than less respected potential colleagues like "Sequah." Although Burroughs Wellcome produced and sold several products more like patent than proprietary or prescription medicines, Wellcome pushed for the firm to invest in research laboratories in chemistry and physiology. These both provided a scientific groundwork for the firm's products and declared the firm's allegiance to science and medicine rather than "quack" cures (Church 379). ${ }^{16}$

Uncle Edward portrayed Tono-Bungay as scientifically based not only in his "Laboratory" but also in his advertising. This draws upon medical terms of the day, perhaps most humorously in the sketch Wells offers of the advertisement designed for some future epidemic, titled "The Happy Phagocyte" ("Tono Bungay ... is a sort of Wooster Sauce for the Phagocyte... . It makes it a perfect wolf for the Influenza Bacillus") (160; bk. 2, ch. 3) (Figure 6). This sketch explains a new scientific discovery in layman's terms for a popular audience. It offers the cachet of scientific discovery and technical jargon: "phagocyte" [a bacteria-eating cell], "Influenza Bacillus." It combines these exotic terms with the familiar phrases of contemporary slang ("a perfect wolf for"), commodities ("a sort of Wooster [Worcestershire] Sauce"), and current events. ${ }^{17}$ As such, the sketch provides an exact analogy for the product Tono-Bungay as it is supposed to be: a carefully researched scientific breakthrough made easily consumable for the general public. The advertisement's reference to Oliver Twist (the phagocyte is captioned, "Oliver asking for more") even provides a tonguein-cheek analogy of the novel's own combination of Dickensian characters and setting with scientific subject matter.

The scientific strategies of Wellcome and Uncle Edward are outwardly similar, but Uncle Edward's use of scientific tropes is - like most of Tono-Bungay - a tremendous bluff. He clearly intends the laboratory still-life at his offices to suggest exciting scientific achievements, but Wells also hints at the inadequacy of that representation: chemists of the early twentieth century would likely have used a condenser rather than a retort in their work, and the mechanical devices that George alludes to are described as broken. The fantasy of laboratory work collapses into dreary reality once George is beyond the office door to view the "dingy wallpaper that had peeled in places," the true state of the electrical machine "patently "on the shelf,"' and to observe that the most frequently used vessels are not chemist's vials but their social analogues, "a whiskey Tantalus and a row of soda syphons" (138; bk. 2, ch. 2). It is equally unlikely that a bottle of Tono-Bungay does anything more for the phagocyte than a bottle of Worcestershire sauce would. The association of Tono-Bungay with chemistry and science masks a bold fraud; Edward aims at only the appearance of scientific analysis and 


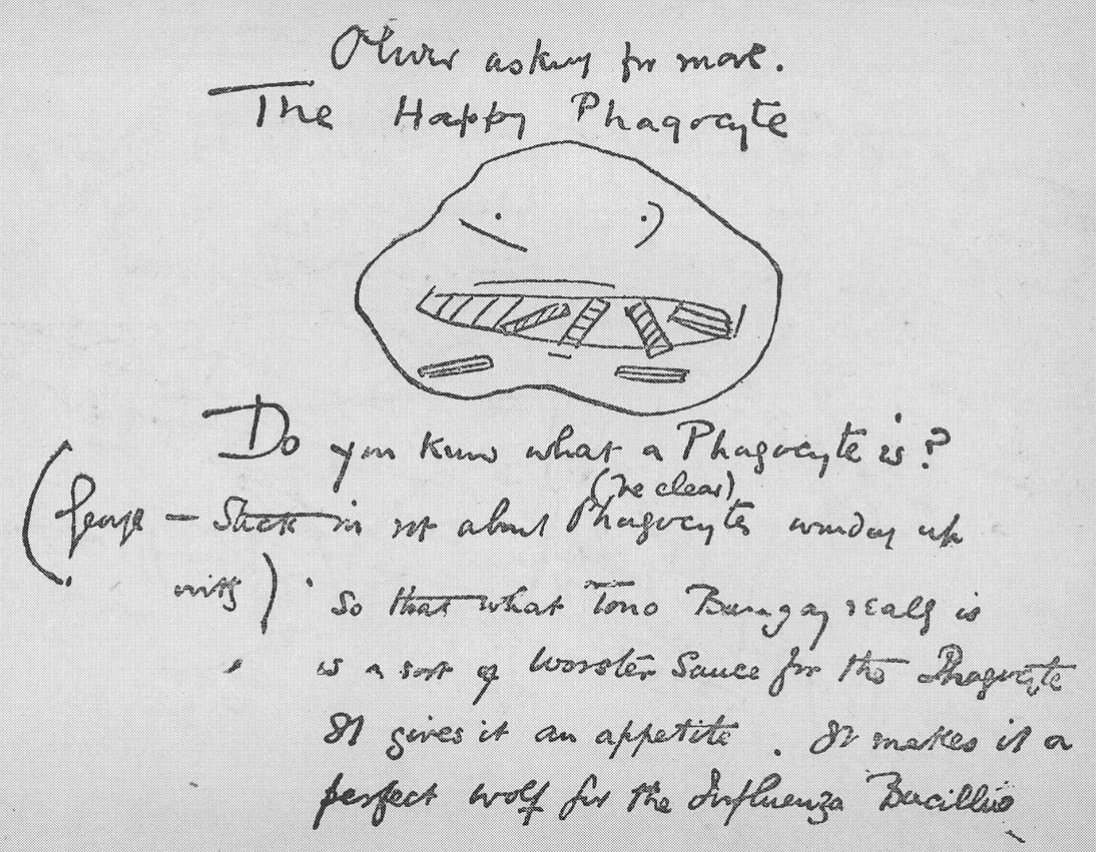

Figure 6. "The Happy Phagocyte.” H. G. Wells. Tono-Bungay: A Novel (New York: Duffield, 1922), 171.

guaranteed quality in his array of products. In contrast, Wellcome's efforts, while certainly useful for publicity, actually did expand the number and type of medicines, assays, and antitoxins on the market and improved the purity and efficacy of the British Pharmacopeia (Church 384). ${ }^{18}$

\section{Advertising and the Brand Name}

TONO-BUNGAY ALSO DIFFERS from the "Tabloid" medicines in using newspapers and hoardings to drive its advertising. Hoardings (advertisements posted on wooden fences or billboards) proliferated during the end of the century, prompting the establishment of a Society for the Checking of Abuses in Public Advertising in 1893. In contrast, Burroughs Wellcome, cautious about its reputation and wanting to differentiate its products from patent medicines, only advertised its medicines in measured tones, with moderate claims, and in medical and pharmaceutical journals. (The young Moggs in Tono-Bungay shows a similar distaste for railway advertising). Wellcome explicitly ruled out both newspapers and hoardings as advertising venues for the firm's medical products, although related products like "Tabloid" Pastilles, as well as the Hazeline and Kepler brands and photography "Tabloids," were more broadly advertised to the lay consumer (Church 382). Wellcome explained that these restrictions should prevent the firm from being "classed as patent medicine vendors and lose ground with the medical profession" (Rhodes James 102). 
Apart from this restraint, Burroughs Wellcome was a leader in the use of advertising. The Wellcome Trust notes Henry Wellcome's early exposure to shrewd advertising technique, in an 1868 newspaper advertisement for his uncle's drugstore in Minnesota, which catches the eye with what at first appears to be a boldface warning of "Indians! ....Are ....On ....The ....War ....Path." Similarly, Burroughs Wellcome arranged for physicians to endorse his products, coined new words to describe his products, blanketed distributors (in this case, doctors and druggists) with promotional materials, and masterminded elaborate displays at exhibits. ${ }^{19}$ Burroughs Wellcome exhibited its products at an exhausting array of exhibitions, medical and nonmedical. For example, the firm put on a display at a Travel Exhibition in London in 1907, the International Press Conference in 1909, and general international exhibitions ranging from the St. Louis Exposition in 1904 and the Franco-British Exhibition in 1908 to the Century of Progress Exposition in Chicago in 1934. Larson lists five distinct exhibitions - like the International Medical and Sanitary Exhibition - at which Burroughs Wellcome set up displays in 1881, the year when Wells was briefly training as a druggist. Wellcome may have distrusted patent medicines like "Sequah," but he had the advertising instincts of a showman like Hartley. For the British Medical Association meeting of 1896, Wellcome brought in a live sheep and tank of cod; he hired a group of Native Americans to be present in full dress for the Chicago Exposition of 1893 (Larson 22-23). The firm made arrangements with various periodicals, exchanging advertising contracts for news coverage of such exhibits (Church and Tansey 57). Even Wellcome's traditional advertisements in medical journals were unusual in that they could run to many pages (Rhodes James 102). In addition, the company distributed promotional materials directly to doctors, nurses, and druggists: ${ }^{20}$ educational booklets and a "Medical Diary and Visiting List" (with an outline of recommended disease treatments using Burroughs Wellcome products) as well as notices and calendars for display on the walls of medical waiting rooms and offices, recalling the almanacs and calendars that patent medicine vendors distributed with advertisements in their pages.

Even such restricted marketing succeeded. In 1890, for example, Burroughs Wellcome's products were judged in a Chemist and Druggist competition to be "most generally effective" (Church and Tansey 59-60). At least one Kepler Malt Extract advertisement in a trade magazine (Chemist and Druggist) urged its readers to "Show this advertisement [in your shop] and you'll show profit," which would allow Burroughs Wellcome to expand its reach to a popular audience. ${ }^{21}$

As the novel is so clearly interested in detailing the rise of not only a man but a brand, it is significant that the "Tabloid" products from Burroughs Wellcome were identified with the very definition of a trademarked brand. Wells, actively monitoring how others referred to his own work (as is evident in his letters), must have been aware of the famous 1903 court case and subsequent appeal centering on the legal status of the brand name "Tabloid." Burroughs Wellcome had registered this term in 1884 to advertise their compressed-powder medicine tablets. Wellcome recalled his invention of the word, choosing it for its "euphonious" sound (Rhodes James 112-13). The courts upheld the protected status of the term "Tabloid" despite its being in part descriptive (which could suggest that it was available to other products as well), and the case became an important point of legal precedent (Burroughs Wellcome \& Co. v. Thompson \& Capper, 1903-1904). Ironically, despite Wellcome's warnings to newspaper publishers and his success in the courtroom, the term "tabloid" continued to be used to describe condensed forms of media, in particular the tabloid newspaper. It also appeared in 
print to identify condensed texts: the "tabloid form of ... [Dickens's] Christmas Carol" or the "tabloid drama" of Shakespeare "boiled down" for popular (music-hall) audiences ("The London Hippodrome" 17; "Tabloid Drama" 5). Even Burroughs Wellcome itself played on this meaning of the word in distributing a booklet titled "Tabloid": A Brief Medical Guide containing condensed medical advice. Overall, the "Tabloid" case brought into the public eye serious questions about the "fancy" (invented) vs. "descriptive" qualities of brand names, their links to newly-invented methods of production, and their value in the marketplace.

Wells demonstrates some awareness of the importance of the brand name - the need for an invented, memorable, suggestive, yet not merely descriptive term - when he depicts George's response to the name when he first sees it on the hoardings: "It was simple and yet in some way arresting. I found myself repeating the word after I had passed, it roused one's attention like the sound of distant guns. 'Tono' - what's that? and deep, rich, unhurrying; - 'Bun-gay!'” (136; bk. 2, ch. 2). An ideal brand name, "Tono-Bungay" combines the suggestion of "tone" and vigor with the exoticizing provenance of many patent medicines, while not technically descriptive at all. In fact, George's "what's that?" suggests that the name is performing its function appropriately in rousing the reader's curiosity.

\section{Quap: The Departure from England}

WHY DOES EDWARD DEMONSTRATE SUCH AFFINITIES with both patent medicine sellers like Sequah and reputable, even scientific proprietary medicine companies like Burroughs Wellcome? That is, why doesn't Wells limit his critique to quackeries alone? The similarities between Tono-Bungay and the "Tabloid" brand proprietary medicines of Burroughs Wellcome may provide a useful bridge between the medicine-based narrative of most of the novel and the odd quap escapade, which has seemed intrusive to many readers, its dreamlike imperial romance a structural challenge in a book otherwise presenting a realist tale of London capitalism. The episode does have certain links to the rest of the novel: it accelerates the disintegration of Uncle Edward's financial empire, and it reminds us that the very name, Tono-Bungay, rouses echoes of imperial conquest "like the sound of distant guns" (136; bk. 2, ch. 2). But quap functions mostly as an interruption of the England-based, Tono-Bungaycentered narrative. Even upon George's return to London, the remainder of the narrative violently shifts away from Tono-Bungay toward his interest in powered motion. ${ }^{22}$

Critics have assailed the novel for structural flaws. Mark Schorer, writing in 1948, laid charges that it "flounders through a series of literary imitations - from an early Dickensian episode, through a kind of Shavian interlude, through a Conradian episode, to a Jules Verne version at the end" (74). The novel's disjunctive rhythm jolts hardest when it shifts into the Conradian quap episode; George himself describes this as "stand[ing] apart from all the rest of my life, detached, a piece by itself"; memories that "stand by themselves"; and a murder that is "unmeaning and purposeless," "strange ... pointless ... incompatibl[e]" with "neat and definite theories" $(344,350,359 ;$ bk. 3 , ch. 4). George presents the story of quap as a strange interlude, tied to his London life only by his underlying financial situation.

Early critics attacked the quap story on just these grounds. ${ }^{23}$ Critics writing since the advent of poststructuralist criticism, however, defend the episode, considering it an echo of Britain's woes. ${ }^{24}$ However, they don't explain why the narrative must leave England in order to depict a radioactive decay of the organism. A conventional Condition of England novel, after all, would be set in England, or at least in Britain. Some modern critics address this 
question by opening up the genre of the novel. They contend that the foreign setting of the quap episode - one of the elements that makes it seem unconnected to the rest of the novel is actually the natural consequence of a narrative focused on empire (financial empire, in this case) and the growth of imperial capitalism. ${ }^{25}$ Others look at energy flows to contextualize the episode, especially considering the novel's interest elsewhere in financial and physical energies. ${ }^{26}$ Finally, Suzanne Keen leans on the disruptive qualities of the quap episode, because it emblematizes her concept of the "narrative annex" (8): an overt structural shift in tone, setting, and genre, which allows a novel to challenge its representational norms. ${ }^{27}$

Overall, criticism on the quap episode has moved from complaints about its disruptive qualities to appreciation of those qualities, while asserting its underlying congruity with the major concerns of the novel. For modern readers, quap powerfully underlines the dynamism and decay of the modern world and the imperial reach of global capitalism. But it is still difficult to understand why the novel must shift to Mordet Island and its store of quap. Other novels press themes of empire and decay without abandoning their core generic or contextual frames. The thematic unity of the episode with the rest of the narrative and its implication in empire does not fully account for what reads as a peculiar and unexpected conjunction of domestic (both in the sense of "British" and "household") medicine with a dangerous imperial adventure, and of domestic realism with imperial romance.

\section{Popular Medicine and the British Empire}

THE NATURE OF UNCLE EDWARD's commodified product line may offer a clue to this link. Patent medicines, like much else in the period, traded on the imperial surge. Nineteenthcentury medicine men typically would claim that their products contained secret ingredients drawn from the lore of native peoples, ${ }^{28}$ often American, perhaps because America was associated with a particular energy in its patent medicine market (Schupbach 283). However, Tono-Bungay hardly mentions America; the whole bent of the novel is on the Englandempire $^{29}$ axis. And although the name "Tono-Bungay" suggests an exotic origin, Edward does not choose to make such associations in his otherwise exorbitant claims for the tonic; that was the province of patent medicines.

Burroughs Wellcome's proprietary medicine, however, does suggest a precedent for Tono-Bungay's sudden turn toward imperial fiction. Burroughs Wellcome rapidly expanded to global dimensions; by 1907 it boasted offices in America, Canada, Australia, and South Africa ${ }^{30}$ In 1901 Wellcome established a tropical research laboratory in Khartoum, and in 1907 he added a boat on the Nile that could serve as a mobile laboratory (Turner 12,21-22).

Wellcome also worked to associate Burroughs Wellcome with travel in the public mind. From the early 1880s, Burroughs Wellcome advertised its production not only of "Tabloid" medicines but also of a range of "Tabloid" medicine cases and chests, ranging from a small first aid kit to a large ship's medicine chest. ${ }^{31}$ An "abridged list" of Burroughs Wellcome products in 1906 dedicates seventeen pages to such cases and chests, minutely differentiated by contents and purpose. The "Alpine" model of "Tabloid' Brand Medicine Pocket Case" ("No. 114"), for example, was designed "for mountaineers, travelers, and tourists" and included "the equipment recommended by the Alpine Club Committee" (Abridged List of Fine Products 8). The "No. 231" medicine case in the "Tropical and Arctic Cases" category, was "Fitted with 'Tabloid' Brand Products ... as recommended in Sir W. Moore's Manual of Family Medicine for India" (14). A 1907 catalogue featured twenty-four pages of medicine 


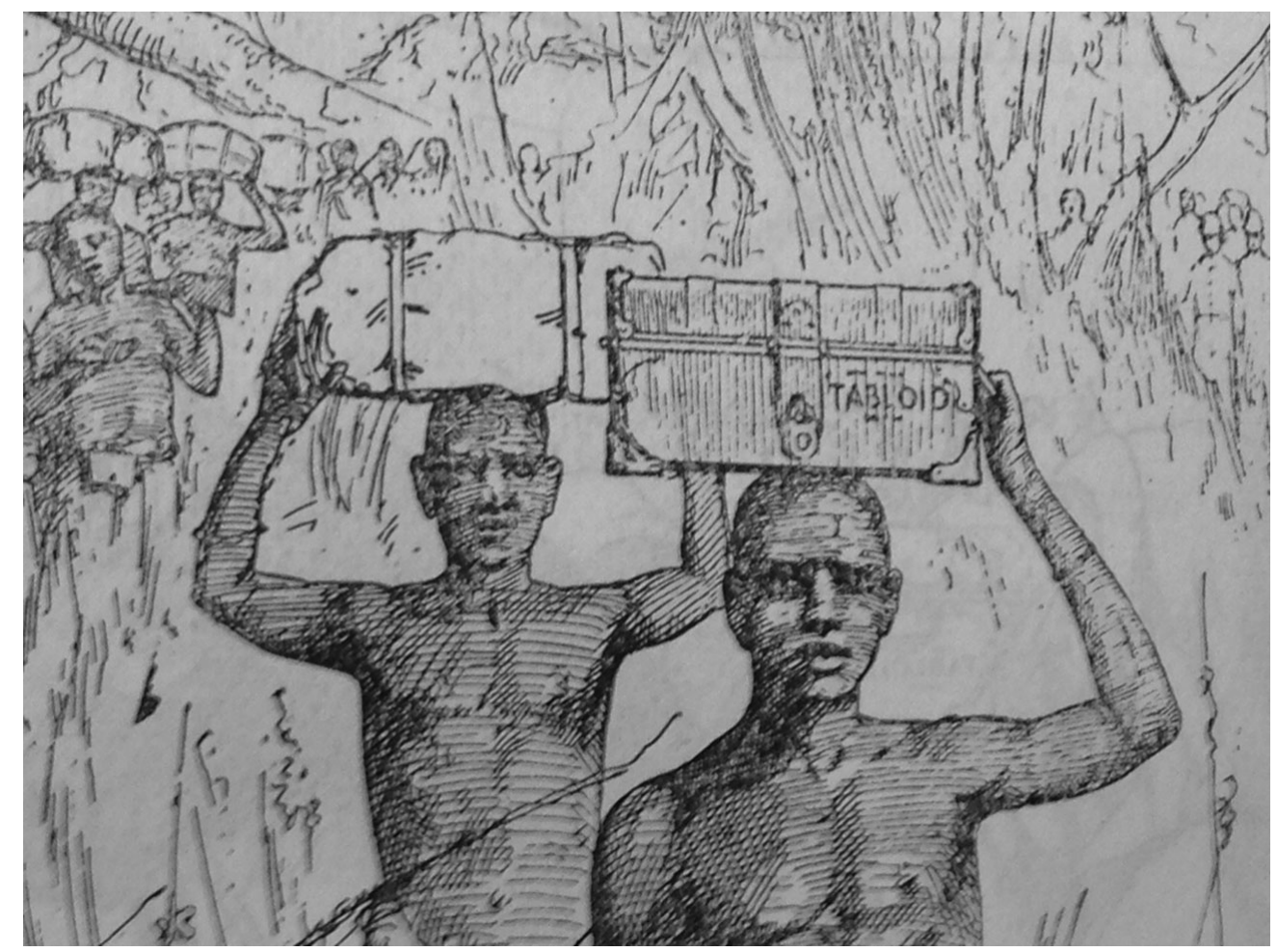

Figure 7. One of the nine "Tabloid" medicine chests provided to Stanley's Emin Pasha expedition. Wellcome Library, London (L0033326).

chests, including No. 258 "The Settler's" and No. 259 "The Motor-Car" (Chemical and Galenical Supplement 21). These chests - titled, labeled, and always paired with the brand name of the products they contained - became a synecdochal advertisement for their contents, the "Tabloids" that condensed a range of medicaments into a compact portable chest.

The "Tabloid" medicine chests became associated not just with travel but specifically with exploration and adventure in exotic corners of the world. Wellcome advertised these chests as crucial to daring expeditions upon air, sea, and mountain. He donated special versions to military forces in the Spanish-American War and the South African War. Famously, Wellcome provided "Tabloid" medicine chests to his friend Henry Stanley for his African explorations (Figure 7). Other well-known turn-of-the-century expeditions with “Tabloids" include May Sheldon (East Africa, 1890-91), Jackson-Harmsworth (Arctic, 1894-97), the Duke of Abruzzi (Arctic, 1899), Nansen (Arctic, 1893-96), and the British National Arctic (1901) and Antarctic (1907-09) Expeditions. ${ }^{32}$

Wellcome also engineered sensational displays around this connection between "Tabloids" and exploration. At the 1886 BMA meeting the firm exhibited one of his Stanley "Tabloid" chests; at the 1895 International Medical Congress it displayed a collection of medicine chests (Larson 22). The Glasgow Herald, reporting on the 1890 International 


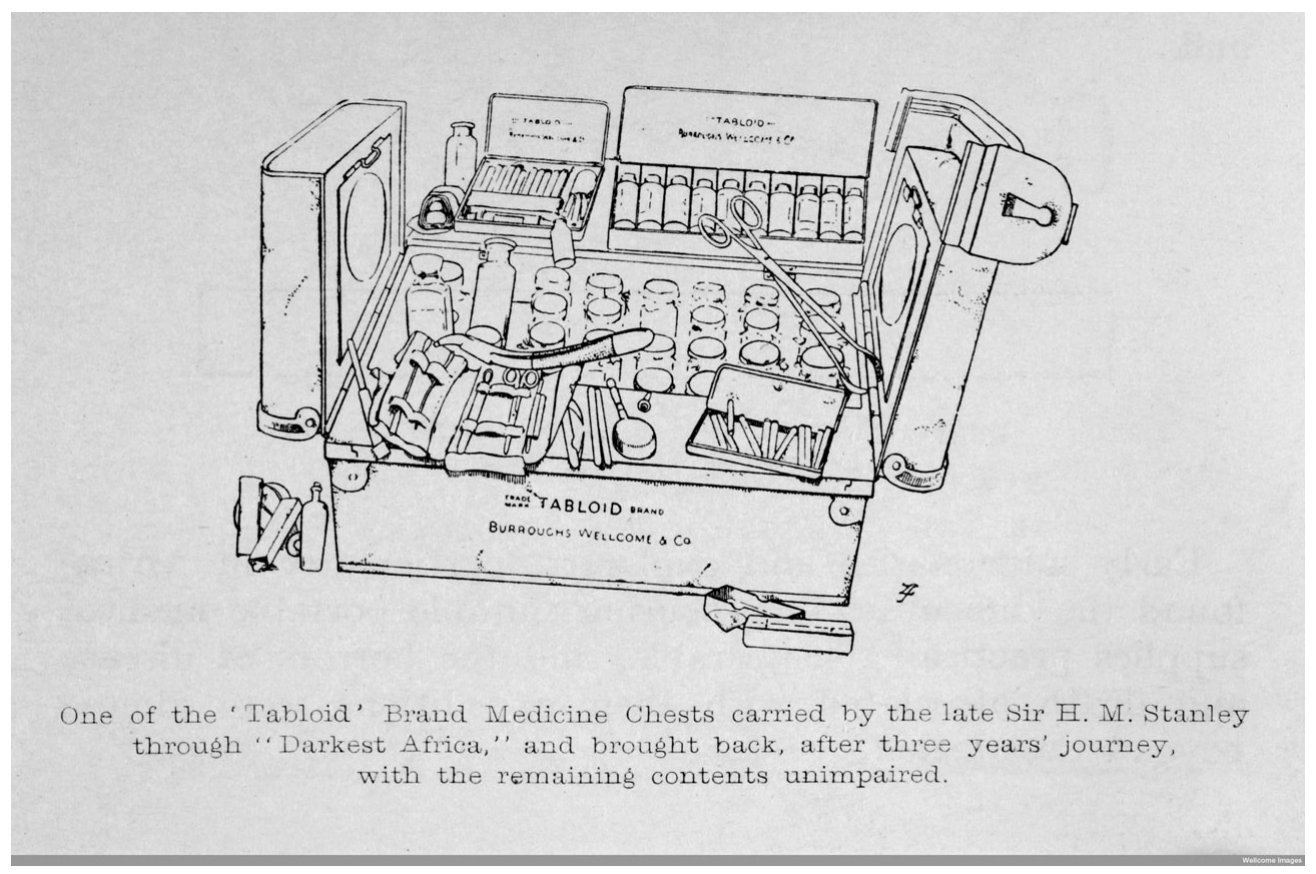

Figure 8. Detail from illustration of "Tabloid" medicine chest "Through Darkest Africa." Anaesthetics 108 (1907). Wellcome Library, London.

Medical Congress, noted with awe "Stanley's medicine chest, with the veritable leather strap by which the native carrier suspended it over his shoulder." In 1913 Wellcome opened a Historical Medical Museum in London for such artifacts.

Burroughs Wellcome also virtually exhibited the "Tabloid" medicine chests in promotional materials, linking each chest to particular expeditions and reprinting testimonials from famous travelers. The "Tabloid" photographic supplies were even celebrated for their use in Scott's doomed Antarctic expedition. A 1907 promotional book included illustrations of "Tabloid" cases being carried by native bearers or beasts of burden "In Central Africa," "Through Darkest Africa," and the like (Anaesthetics [109]) (Figure 8). A photomechanical print displayed in 1908 presents dramatic color illustrations demonstrating the association between "Tabloid" and exploration ${ }^{33}$ (Figure 9).

Any Briton consuming medical or pharmaceutical products and services - certainly Wells, who had a history of ill health - is likely to have encountered such advertisements for "Tabloid" medicine chests on the calendars, posters, and memorandum-books for doctors, nurses, and druggists that Burroughs Wellcome distributed widely. The firm also placed advertisements in newspapers. The London Standard advertised the Burroughs Wellcome exhibit at the 1892 Royal Naval Exhibition, open to the public; Stanley's name was prominently mentioned.

Furthermore, the "Tabloid" brand was commonly mentioned in news stories and books about such travelers. British newspapers eagerly conveyed the details of expeditions, 


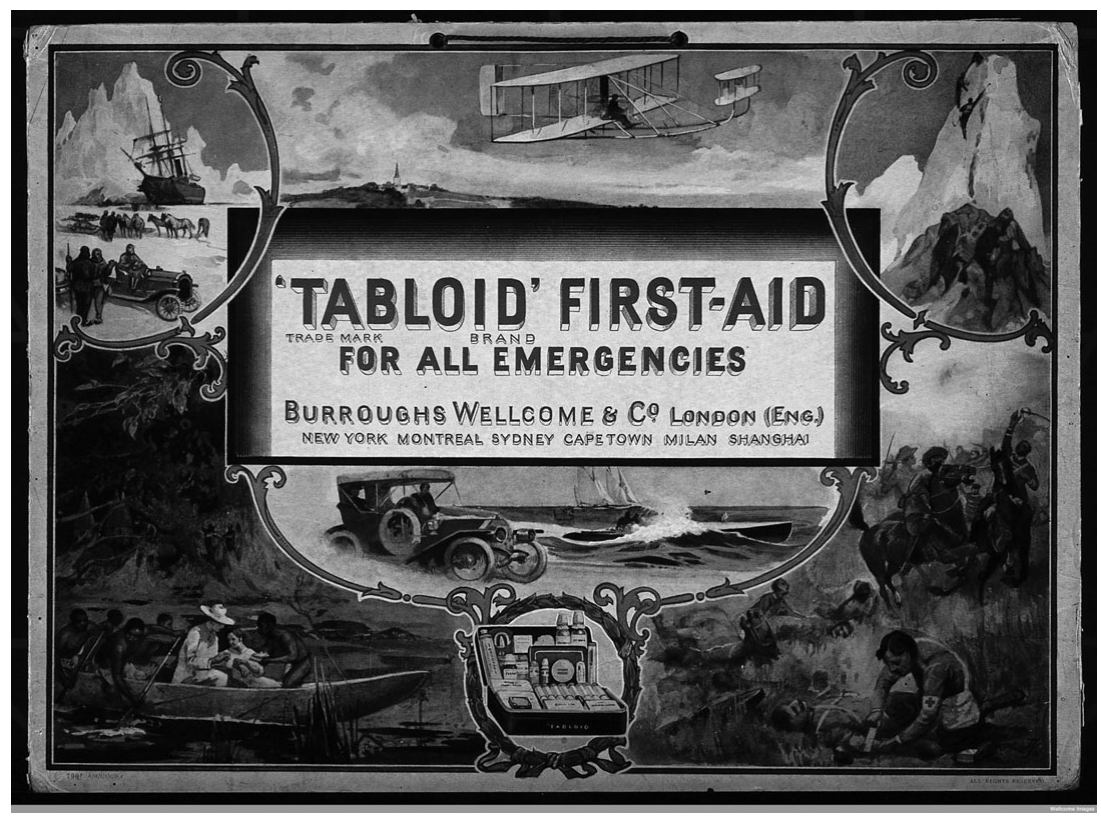

Figure 9. Pharmacy sign advertising Tabloid first aid kits as the companion of explorers and adventurers. Wellcome Library, London (V0010811).

including their use of "Tabloid" medicine chests, and many travelers publically praised the "Tabloid" chests (Church and Tansey 60; Larson 16-19; Rhodes James 218-19, 100). The "Tabloid" medicine chests were featured in Stanley's public lectures and books (notably In Darkest Africa) as well as books by two of his associates, Thomas Parke and Thomas Stevens (Youngs 176). ${ }^{34}$ The Times in 1898 (with other papers) printed a public-relations squill from Burroughs Wellcome featuring an it-narrative: the adventures of "Emin Pasha's medicine chest" in Africa. And in 1894, Wellcome arranged for the distribution of 200 copies of a favorable newspaper article quoting Stanley (Beckett 126).

Wellcome surely believed his firm would profit from the analogy between these travellers' boldness and his own firm's metaphorical explorations into pharmaceutical researches. In the aggregate, Ryan Johnson argues, advertisements and publicity for the "Tabloid" medicine chests helped to develop what David Arnold calls a "discourse of tropicality," of heat, rich resources, and danger, especially associated with colonized lands (258). It is this discourse that Wells draws upon in modeling Mordet Island. The depiction of such expeditions in advertising matter was an integral aspect of turn-of-the-century imperial ambition, including the "Scramble for Africa." Thomas Richards and Anne McClintock, among others, have shown the extent to which consumable goods - soap, tea, cocoa, and popular medicine drove the late-Victorian commodification of the imperial project that we might call the "branding of the British empire." The "Tabloid," as a popular, aggressively-marketed and "exhibited" consumable that enabled the "opening up" of unexplored lands, helped leverage that shift. By 1911, the firm was boasting, "Mr. Joseph Chamberlain has taught the nation to think Imperially - Burroughs Wellcome \& Co work Imperially" (Modern London 29). 
The expansion of empire had become increasingly controversial, with reports in European newspapers of the debacle that occurred when Stanley left a "Rear Column" of men behind at camp during the Emin Pasha expedition (1887-90). Tim Jeal's discussion of the episode documents how readily empire-building can devolve into barbarism. ${ }^{35}$ The scandal of Stanley's Rear Column (or "Rear Guard") revived earlier concerns that such expeditions were brutal, motivated by greed rather than pure ideals. It provided a likely model for Conrad's Kurtz in Heart of Darkness (1899) and possibly also George's murder of the native on Mordet Island.

But Wellcome doubled down on his association with Stanley in the midst of the controversy. ${ }^{36} \mathrm{He}$ wrote a letter to the Times rebutting one allegation that the medicines left to the ill-fated group were "worthless." Wellcome declares, "It is well known that our firm equipped the expedition with all their medicines." He asserts the quality of the tabloid drugs, quotes Stanley and others endorsing the medicines, recalls that one of the nine chests had been exhibited as a "souvenir" of Stanley's trip, and offers to let readers examine another medicine case at the firm's offices in Snow Hill. ${ }^{37}$ This strengthened readers' associations between "Tabloid" drugs and the darker aspects of Stanley's "Darkest Africa" projects, of which George's actions on Mordet Island form an echo. Perhaps Wellcome's commitment to these traveling chests arose from his passion for collecting foreign artifacts; ${ }^{38}$ but it also suggests how closely the economic interests of Burroughs Wellcome were tied to British imperial ones, as Johnson notes (253). In fact, Wellcome's sponsorship of explorers from all countries suggests that - as Richards has argued - the commodity (specifically the export of a supposed surplus of commodities) can substitute for the nation as an organizing principle in the imperial project (Commodity 128-30). After all, imperial exploration and settlement provided the firm with not only a reliable market for their products among explorers, settlers, and natives - Stanley praises the efficacy of the medicines for both "my black men" and "my white men" - but also resources for future products (Burroughs Wellcome, Evolution of Journalism 287).

For Burroughs Wellcome had another link to the kind of aggressive imperial capitalism represented by George's attempt to tie down the supply of quap. The British firm instigated a similar strategic race to Africa to secure financial advantage of a rare, poisonous resource. Wellcome, who had journeyed within Latin America seeking cinchona trees for quinine in 1878, recognized the economic possibilities when he heard Sir Thomas Fraser give an 1885 lecture on the medical uses of an African arrow poison. Wellcome conferred with Fraser about the substance, which acts on the heart, and sent an envoy to Africa to arrange for Burroughs Wellcome to purchase the Strophanthus Kombé seed pods from which the poison was made - it promised to be a useful substitute for digitalis. ${ }^{39}$ This project secured the firm's reputation as a scientifically grounded, modern pharmaceutical company and partner of medical research (Church 383-84). Extracts of various types of Strophanthus made up nearly a third of the botanical exhibits that Burroughs Wellcome displayed at the FrancoBritish Exhibition in London in 1908. However, the firm's corner on the market prompted complaints of monopoly trading and artificially high prices; for years the use of Strophanthus was hampered by the firm's control over access to the potent variety of the plant. If, as Markku Hokkanen argues, "Colonial knowledge was essentially constructed and constituted 'in travel'" (593), then the Strophanthus episode - like the quap episode - serves as an anchor of imperial knowledge. Because knowledge is also a product of global capitalism, it is driven as much by the demands of the "Tabloid" (or Tono-Bungay) as by any national imperative. 
This episode demonstrates the extent to which, as Abena Dove Osseo-Akare argues, "the search for new drugs [bioprospecting] was also a factor in the scramble for Africa" (272).

The association of the "Tabloid" brand with exploration and empire thus provides a possible precursor for the "quap" escapade in the novel, where the narrative demonstrates a sudden break in mode, setting, and theme. Edward had fantasized about cornering the market in some crucial active element, even before he thought of Tono-Bungay. "Take a drug - take ipecac, for example," he explains. "Take a lot of ipecac. Take all there is! See? There you are! There aren't unlimited supplies of ipecacuanha - can't be! - and it's a thing people must have. Then quinine again! You watch your chance... and collar all the quinine." George dismisses this as "a sort of irresponsible monkey trick that no one would ever be permitted to do in reality" (74; bk. 1, ch. 3). But in fact it had been done, essentially, when Burroughs Wellcome arranged to become the sole source in England for the pure (e.g., active) variety of Strophanthus. And it is exactly this that Edward and George attempt to do with quap, which they hope to secure as a crucial element of a new form of lighting, but which proves to be bioactive (and thus a potential medicine) as well. ${ }^{40}$

Finally, Burroughs Wellcome's "Tabloid" brand presents one other aspect that resonates with the novel's puzzling blend of patent medicine, adventure travel, and mechanical invention. Few critics have discussed the centrality of powered flight in the novel, as an increasingly important outlet for George's inventiveness and a sublimation of his sexual desire, or as a metaphor for his and his uncle's tumultuous social mobility. But just as the money from Tono-Bungay underwrites George's forays into powered flight, which eventually take over the novel, "Tabloids" helped enable early flight. That is, the "Tabloid" brand is repeatedly linked with not just imperial exploration but new modes of powered transport especially air travel - in its service, perhaps because aeroplanes and motor-cars were often equipped with a small medicine chest. The public face of the "Tabloid" brand was soon partnered with these new modes of transportation, as is clear from the prominence of air and motor travel in the colorful 1908 advertisement discussed earlier. Wellcome provided "Tabloid" medicine chests to a number of pioneering aviators: Andrée, Beaumont, Vedrines, Pecquet, Louis Blériot, Wellman, and C. C. Turner (Romance of Exploration; Church and Tansey 60). In 1928, promotional materials boasted, "practically every famous airman has carried as his sole first-aid outfit a "Tabloid' Equipment" ("Tabloid," A Brief Medical Guide 5). And in the Burroughs Wellcome book The Romance of Exploration and Emergency First Aid (1934), the chapter divisions indicate the categories in which Wellcome saw the firm excelling: "Pioneer Heroes of Africa," "Heroes of Polar Exploration," "Pioneers of Air Travel." George's fascination with powered flight seems largely unmotivated by his life experiences; but "Tabloids" traveling chests suggest that the unusual grouping of patent medicine with imperial exploration and innovative air travel was particular to this historical moment.

\section{Conclusion}

WE CANNOT KNOW IF WELLS was thinking of Burroughs Wellcome and the "Tabloid" brand while writing Tono-Bungay. However, the "Tabloid" brand and its imperial connections do provide an important context for the novel and a reminder that the domestic, popular world of patent and proprietary medicines and the imperial, political one of their raw resources are not as distant as the novel makes them seem. Indeed, the advertising and marketing 
efforts of Burroughs Wellcome ensured that its "Tabloid Medicine Chests" were integrally tied in the public mind with the efforts of explorers pushing through the African jungle, missionaries extending the reach of the Church in India, and pilots expanding into the empire of air. Other firms, cocoa vendors and the like, certainly drew on the authority and energy of the imperial project to promote their wares, but Burroughs Wellcome was a forerunner not only in the establishment of trademark brands as a legal concept but also in the branding of the British empire - its association with particular products. Burroughs Wellcome and its "Tabloid Medicine Chests" provide an important and very public reminder of how integrated were the markets for proprietary medicine and the raw resources derived from imperial lands. Tono-Bungay is a novel deeply concerned with the imbrication of capitalism, branding, and imperial travel, which are indeed the new "conditions" of England. If Edward's fantastical product, Tono-Bungay, represents the new relations formed by imaginative work in these endeavors, its story was written in a space crucially shaped by the familiar name of the "Tabloid" and the global reach of its author, Burroughs Wellcome.

\section{Florida State University}

\section{NOTES}

My thanks to William Schupbach and Joseph Gabriel for their comments on this topic and to the staff at the Wellcome Collection for their assistance.

1. The novel was serialized in the English Review between December 1908 and March 1909 and published in volume form with Duffield in New York in 1908 and Macmillan in London in February 1909.

2. Wells, "Preface to the Atlantic Edition (1925)," Tono-Bungay (OUP), 3. All further quotations from Tono-Bungay will be to this edition, which is based on Wells's 1925 revisions to the novel.

3. The pharmacy depicted in Figure 1 would have been a half-century or more before George's youthful memories, but many of these elements remain in Uncle Edward's shop (for example, the colored-water bottles as advertising display in the window).

4. Young discusses American patent medicines, which were known for their sensational advertising, but British patent medicines also relied on advertising to gain trade.

5. See, for example, Ueyama 3; Smith 343-45. Porter, among others, has shown that popular medicine was commodified to a certain extent even before the nineteenth century, but the later nineteenth century was characterized by increasing regulation and commodification of popular medicines and the emergence of proprietary brand medical products.

6. Ueyama describes how market forces at this time helped produce the commodification of regular medicine in ways that blur the distinctions between patent, proprietary, and professional medicine. However, proprietary medicine companies did take pains to ensure that their products did not fall under any of the patent medicine categories most strictly regulated or taxed.

7. For discussion of some similarities between Wells's novel and the 1902 trial about the status of Coca-Cola, see Weissmann 1279.

8. I am grateful to William Schupbach for a fruitful exchange in which he shared his insight about possible parallels between "Sequah" and Uncle Edward. Personal email from William Schupbach, Librarian, Iconographic Collections, Wellcome Library, 13 November 2012.

9. Helfand notes the longtime association between print advertising and purveyors of patent medicines (44-45).

10. Richards also invested in a new "Sequah Medicine Company" after the failure of Hartley's Sequah in 1895. He closed it down in 1909 (Schupbach 313). 
11. This was not uncommon; Gabriel discusses how the reluctance to patent new discoveries meant that pharmaceutical firms' research could be readily poached by competitors $(113 ; 115-18)$.

12. Varieties of Pastilles included glycerin and black current, "laxative fruit," lemon, linseed, and menthol as well as cocaine and codeine (Burroughs Wellcome, Anaesthesics 130).

13. See "Forced March" tabloid brand, Burroughs Wellcome Co. Wellcome Library, London. Image no. M0013157. <http://wellcomeimages.org/indexplus/image/M0013157.html>.

14. Schupbach points out that Burroughs Wellcome's Kepler Malt Extract, one of its earliest products, was not far from a patent medicine like Tono-Bungay. Personal email, 13 Nov. 2012.

15. Wellcome chose Wandsworth as the site for the firm's 1883 manufacturing facility specifically for its clean air and water, as "in the making of fine products, the soot and smoke of London is very likely to contaminate the goods" (Rhodes James 107).

16. The firm established the Wellcome Physiological Research Laboratories (1894), the Wellcome Chemical Research Laboratories (1897), and the Wellcome Tropical Research Laboratories (1901).

17. Ilya Ilyich Mechnikov was awarded the Nobel Prize in December 1908 for naming the phagocyte. The discovery of phagocytes had made them familiar in public discourse during the period when Wells was writing the novel. For example, a Daily Express review of Ray Lankester's book The Kingdom of Man in 1907 concludes with a description of the phagocyte, concluding, "happy the man whose phagocytes are healthy" ("Man's Fight with Nature" 4). A 1904 Daily Mail article on "Burmah Cup," a new temperance beverage that also "frightens microbes," comments, "Phagocytes, as everyone knows, are the kindly constituents of the blood which down microbes" (14). Wells, with his scientific interests, would certainly have known about the phagocyte; more important, he could assume that any generally literate reader would also. As for influenza, Uncle Edward would not have been the only vendor to make such claims; see, for example, the advertisement "Bovril Repels Influenza."

18. Interestingly, despite this "scientific" marketing strategy, both Wellcome and Uncle Edward also designed a set of advertisements around history. After 1898 Wellcome asked his staffer Dr. C. J. S. Thompson, a medical historian, to guide a series of "antique advertisements" putting "Tabloid" brand medicines in the context of medical history (Church and Tansey 159).

19. Burroughs planned and led some of the efforts to enlist doctors and hospitals as regular customers and endorsers. See Rhodes James 75-77.

20. Apparently it also distributed to "American and English consulates ... leading clergy, and plantations in the colonies" (Church and Tansey 58).

21. Chemist and Druggist 27 (27 Jan. 1894): 113, qtd. in Church and Tansey 57.

22. James notes that there was at the time a patent medicine that, like quap, was (or was supposedly) radioactive: Pasqui's Uranium Wine (117). As he points out, this episode also links "quap" in the novel to "Cowap," a "quack chemist" with whom Wells had briefly studied in his youth. See Wells's Autobiography, where he claims that Uncle Edward is "drawn largely" from this figure.

23. Hubert Bland, with whose household Wells had just been acrimoniously entangled, in 1909 considered the chapter to be "a wholly irrelevant account." He calls it "an episode that hinders rather than helps the progression of the story and does nothing whatever towards the development of any of the characters" (Daily Chronicle (9 Feb. 1909): 3; qtd. in Parrinder 147). Macy, in 1922, complains that "for no reason at all [Wells] sent his hero in search of a mysterious metal called "quap"" (275). Macy deplores this overarching tendency in Wells, who "has succeeded in two kinds of fiction, which he should keep distinct, the Jules Verne romance and the novel of present-day life. He persists in putting the two in the same book, and they simply will not blend” (274). Indeed, he says, “'Quap' destroys the illusion of the book," (275). Somewhat less caustic, Walter Allen in 1958 calls the quap episode "brilliantly done, but ... plainly an afterthought" (317).

24. Lodge led the reversal, noting an "explicit connection . . . between the quap and the condition of England. It is difficult therefore to sustain the charge that the episode is an irrelevance" (252-53). Hammond (2001) agrees that quap, "in reality an integral part of the overall design," amplifies the 
"dominating theme" of the book: "the broad slow decay of the great social organism of England" (193).

25. Squillace (1994), for example, sees the quap expedition as "the logical international consequence of the national system [of commerce]" (672). Kupinse (1999) sees the novel as united under the sign of "waste," so that the quap episode unites "both Edward's capitalist schemes and George's scientific exploits" in "a waste-driven series" encompassing both England's capitalist system and the global reach it demands (61). Kupinse also argues that the series of literary imitations - from Dickens to Shaw to Conrad - that Schorer deprecates in fact serves as a quasi-modernist "sampling" of three British authors prominently known for their critiques of British policies on the poor, the working classes, and the colonial peoples (66-67).

26. Richards (1993) sees continuity in that both Tono-Bungay and quap offer illusory promises of free, low-entropy energy, the search for which has always been global. Esty (2012) sees disruption: the quap episode represents the novel's oscillation from the inflationary narrative of "bogus technology, mass marketing, and rampant speculation" to the deflationary one of "bankruptcy, economic collapse, and empty consumerism"; although that the incident is "entirely consistent with the main plot at a thematic and symbolic level" because it maintains a "focus on the underlying problem of nonproductivity" (122).

27. The quap episode and its murder thus, she argues, give Wells the opportunity to reject the redemptive narrative that was common in traditional Condition of England novels (168).

28. In discussing Sequah as part of a tradition of patent medicine figures claiming association with Native Americans, Schupbach notes, "Even the reputable Burroughs Wellcome Co. used Red Indians to draw attention to its sale of Florida mineral-water at a Chicago exhibition in the 1890s" (285).

29. That said, the entrepreneurs in patent medicine were not overly nice in distinguishing between the various exotic locales they claimed as origins for their products. One man who was prosecuted for infringement of the Sequah trademark won his case by demonstrating the availability to anyone of the term "Indian oil," given the importance of India to the British empire; another trading on this conflation of "Red Indian" culture with the Indian subcontinent peddled a "Sepoy" brand "Indian Balm," a knockoff of "Sequah's Indian Oil."

30. See cover of Chemical and Galenical Supplement 1907.

31. Beckett argues that Burroughs actually originated the idea of manufacturing specialized medicine chests as a promotional scheme (112-13), but Wellcome devoted much energy to designing, extending, and promoting the product line of "Tabloid" brand medicine cases and chests.

32. Later travelers with "Tabloid" chests included Richard E. Byrd, Charles Lindbergh, Robert Peary, Calbraith Rodgers, Teddy Roosevelt, and Ernest Shackleton. The firm claimed that "Tabloid" equipments "were First, Second, and Third at the North Pole and First and Second at the South Pole." ("Tabloid": A Brief Medical Guide 7). Wellcome provided "Tabloid" chests to rivals Roald Amundsen and Robert Scott as the Norwegian and British expeditions each sought to be the first to reach the South Pole (1910-12).

33. McFarlane identifies some of the figures depicted in this advertising sign as "William Gladstone felling trees, Ernest Shackleton traversing the Antarctic, or Louis Blériot flying across the English channel" (205). This colorful 1908 process print showing the use of "Tabloid" brand medicine chests in foreign lands and desperate conditions was probably displayed in pharmacies, hanging from a cord. The Wellcome Library's copy of this advertisement is from "Boots cash chemists, 35 High Street, Haddington, East Lothian, Scotland" and still has its cord (Personal email from William Schupbach, Librarian, Iconographic Collections, Wellcome Library. 13 Nov. 2012). It is likely that this or similar materials were provided for display to the "chemists throughout the world" who sold "Tabloid" brand medicine chests, given that the firm also distributed practitioners' diaries on a comprehensive scale. If all Boots stores sold the "Tabloid" chests, in 1908 these advertisements would have been available at 349 locations. (Chapman 90, 85. See also Roberts 24). The phrase "chemists throughout the world" 
frequently appeared in Burroughs Wellcome promotional materials, promoting the wide availability of their products.

34. Richards, among others, notes that Stanley studded this text with many product names (Commodity 129). However, his praise of "Tabloid" products in particular was not only effusive, it was repeated in multiple contexts, and Wellcome did much to sustain the impression of a special relationship between his firm and the famous explorer.

35. Jeal's chapter is even titled, "Was the Emin Pasha Expedition Piratical?" (407-14)

36. Beckett argues, in discussing an earlier controversy, that Wellcome was "defending a shared reputation" (e.g., that of both Stanley and the pharmaceutical firm that had associated itself with his expeditions $[125,127])$. In the Rear Column letter Wellcome focuses on defending the quality of his medicines, although he does emphasize the strong link between "Tabloids" and Stanley.

37. Wellcome continued to reprint descriptions of "the famous Rear Guard" medicine chest in the promotional materials distributed by the firm for years after. See, for example, Anaesthetics 75 .

38. Hill shows the extent to which Wellcome's collecting was dependent in many ways on the success of the Burroughs Wellcome business (374-76).

39. Holmes in the Pharmaceutical Journal gives a somewhat different story, reporting that John Moir, an agent of an African steamer company, contacted Burroughs Wellcome about importing this rare and valuable resource (313). The firm made a tincture and eventually produced "Tabloid" brand Strophanthin from this resource. See Wellcome, From Ergot to 'Ernutin' 115. Burroughs Wellcome claimed a monopoly of the drug due to these negotiations (Hokkanen 599).

40. Interestingly, if Wells was familiar with the Strophanthus episode, it may have prompted him to identify quap - his fictional version of a rare African resource - as poisonous. That notion would not have derived from common knowledge, as radioactive materials were not identified as carcinogens until 1909 (Mendelson xvii).

\section{WORKS CITED}

Allen, Walter. The English Novel: A Short Critical History. New York: Penguin, 1971.

Arnold, David. The Tropics and the Traveling Gaze: India, Landscape, and Science, 1800-1856. Seattle: U of Washington P, 2006.

Bartrip, Peter. "Secret Remedies, Medical Ethics, the BMJ." The Codification of Medical Morality. Ed. Robert Baker. Boston: Kluwer Academic, 1995. 191-204.

Beckett, Chris. "Attitudes to Political and Commercial Endorsement in the Business Papers of Silas Mainville Burroughs, with Particular Reference to Henry Morton Stanley." Medical History 52.1 (2008): 107-28.

Bland, Hubert. Rev. of Tono-Bungay. Daily Chronicle (Feb. 1909): 3.

"Bovril Repels Influenza (advertisement)." Illustrated London News, no. 3593 (Saturday, Feb. 29, 1908): 324. Illustrated London News Historical Archive. Web. 17 Nov. 2015.

British Medical Association. Secret Remedies: What They Cost and What They Contain. London: British Medical Association, 1909.

“Burmah Cup.” Daily Mirror (20 July 1904): 14.

Burroughs Wellcome. Abridged List of Fine Products Issued by Burroughs Wellcome \& Co, 1906. USA, 1906. Wellcome Foundation. Archives and Manuscripts, WF/M/GB/01/07/02. [Circulars Book 6 - Part 2]. Wellcome Library, London.

. Anaesthetics: Ancient and Modern: An Historical Sketch of Anesthaesia. London: Burroughs Wellcome, 1907.

- Chemical and Galenical Supplement 1907. London: Burroughs Wellcome, 1907. Wellcome Foundation. Archives and Manuscripts, WF/M/GB/01/07, no. 118. [Circulars Book 6]. Wellcome Library, London. 
. The Evolution of Journalism Etcetera. Souvenir of the International Press Conference London 1909. London: Burroughs Wellcome, 1909.

- Modern London: Souvenir of the First Universal Races Congress, London, 1911. 1911.

. The romance of exploration and emergency first-aid from Stanley to Byrd. New York: Burroughs Wellcome, [1934].

- "Tabloid": A Brief Medical Guide (for Foreign and Colonial Use Only). London: Burroughs Wellcome. After 1928. Wellcome Library, London, Image no. M14856.

- Wellcome's Medical Diary and Visiting List 1907. London: Burroughs Wellcome, 1907. Wellcome Foundation. Archives and Manuscripts, WF/M/PB/003/20. Wellcome Library, London.

Church, Roy. "Trust, Burroughs Wellcome \& Co. and the Foundation of a Modern Pharmaceutical Industry in Britain, 1880-1914." Business History 48.3 (2006): 376-98.

Church, Roy A, and E. M. Tansey. Burroughs, Wellcome \& Co.: Knowledge, Trust, Profit and the Transformation of the British Pharmaceutical Industry, 1880-1940. Lancaster: Crucible, 2007.

Corley, T. A. B. "Beecham's, 1848-2000. From Pills to Pharmaceuticals." Beecham's, 1848-2000: From Pills to Pharmaceuticals. Lancaster: Crucible Books, 2011.

“Emin Pasha’s Medicine Chest.” Times 35671 (11Nov. 1898): 4. Times Digital Archive. Web. 29 Nov. 2012. [Digitized under "By his will Mr Ralph Disraeli"].

Esty, Jed. Unseasonable Youth: Modernism, Colonialism, and the Fiction of Development. New York: Oxford UP, 2012.

Gabriel, Joseph M. Medical Monopoly: Intellectual Property Rights and the Origins of the Modern Pharmaceutical Industry. Chicago: U Chicago P, 2014

Hammond, John R. A Preface to H. G. Wells. Harlow and New York: Longman: 2001.

Helfand, William. Quack, Quack, Quack: The Sellers of Nostrums in Prints, Posters, Ephemera \& Books. Chicago: U of Chicago P, 2002.

Hill, Jude. "Globe-trotting medicine chests: tracing geographies of collecting and pharmaceuticals." Social \& Cultural Geography 7.3 (June 2006): 365-84. Taylor \& Francis Online. Web. 13 March 2013.

Hokkanen, Markku. "Imperial Networks, Colonial Bioprospecting and Burroughs Wellcome \& Co.: The Case of Strophanthus Kombe from Malawi (1859-1915)." Social History of Medicine 25.3 (2012): 589-607.

Holmes, E. M. "The Commercial History of Strophanthus.” Pharmaceutical Journal (17 March 1906): $312-14$.

"International Medical Congress." Glasgow Herald 191 (Monday, 11 Aug. 1890): 4. 19 ${ }^{\text {th }}$ Century British Library Newspapers. Web. 4 April 2013.

James, Simon J. Maps of Utopia: H. G. Wells, Modernity, and the End of Culture. Oxford: Oxford UP, 2012. Jeal, Tim. Stanley: The Impossible Life of Africa's Greatest Explorer. New Haven: Yale UP, 2007.

Johnson, Ryan. "Tabloid Brand Medicine Chests: Selling Health and Hygiene for the British Tropical Colonies." Science as Culture 17.3 (2000): 249-68.

Keen, Suzanne. Victorian Renovations of the Novel: Narrative Annexes and the Boundaries of Representation. Cambridge: Cambridge UP, 1998.

Kupinse, William. "Wasted Value: The Serial Logic of H. G. Wells's Tono-Bungay." NOVEL 33.1 (1999): 51-72. JSTOR. Web. 1 Dec. 2012.

Larson, Frances. An Infinity of Things: How Sir Henry Wellcome Collected the World: How Sir Henry Wellcome Collected the World. Oxford: Oxford UP, 2009.

Lodge, David. The Language of Fiction: Essays in Criticism and Verbal Analysis of the English Novel. London: Routledge, 1966.

“The London Hippodrome.” Times 38519 (18 Nov. 1907): 17. Times Digital Archive. Web. 30 Nov. 2012.

Macy, John Albert. The Critical Game. New York: Boni and Liveright, 1922.

"Man's Fight with Nature [Rev. of Lankester, Kingdom of Man]." Daily Express (27 Feb. 1907).

McClintock, Anne. Imperial Leather: Race, Gender, and Sexuality in the Colonial Contest. New York: Routledge, 1995. 
McFarlane, Ross. “Tabloid.” Lancet. 373.9659 (17 Jan. 2009): 205.

Mendelson, Edward. "Introduction.” Tono-Bungay. Ed. Patrick Parrinder. New York: Penguin, 2005.

Nevett, T. R. Advertising in Britain: A History. London: Heinemann, 1982.

Osseo-Asare, Abena Dove. "Bioprospecting and Resistance: Transforming Poisoned Arrows into Strophantin Pills in Colonial Gold Coast, 1885-1922." Social History of Medicine 21.2 (2008): 269-90.

Parrinder, Patrick, ed. H. G. Wells: The Critical Heritage. London and Boston: Routledge \& Kegan Paul, 1972.

Porter, Roy. Health for Sale: Quackery in England, 1660-1850. Manchester: Manchester UP, 1989.

Rhodes James, Robert. Henry Wellcome. London: Hoder \& Stoughton, 1994.

Richards, Thomas. The Commodity Culture of Victorian England: Advertising and Spectacle, 1851-1914. Stanford: Stanford UP, 1991.

- The Imperial Archive: Knowledge and the Fantasy of Empire. London: Verso, 1993.

Roberts, Cecil. Achievement: A Record of Fifty Years' Progress of Boots Pure Drug Company Ltd.[18881938]. [n.p.], 1939.

"Royal Naval Exhibition.” London Standard 20,848 (2 May 1891): 1.

Schorer, Mark. "Technique as Discovery." Hudson Review 1.1 (1948): 67-87.

Schupbach, William. "Illustrations From the Wellcome Institute Library: Sequah: An English "American Medicine'-Man in 1890." Medical History 29: 272-317.

Smith, F. B. The People's Health 1830-1910. London: Croom Helm, 1979.

Squillace, Robert. "Bennett, Wells, and the Persistence of Realism." Columbia History of the British Novel. Ed. John J. Richetti, John Bender, Deirdre David, and Michael Seidel. New York: Columbia UP, 1994. 658-84.

Stanley, Henry. The Autobiography of Sir Henry Morton Stanley, G.C.B. Cambridge: Cambridge UP, 2011. . In Darkest Africa: or the Quest, Rescue, and Retreat of Emin, Governor of Equatoria. London: Sampson, Low, Marston, Searle, and Rivington, 1890.

“Tabloid Drama: Shakespeare 'Boiled Down' for the Music Halls.” Daily Express (14 March 1904): 5.

Turner, Helen, and Sir Henry Solomon Wellcome. Henry Wellcome: The Man, His Collection and His Legacy. London: Wellcome Trust and Heinemann, 1980.

Ueyama, Takahiro. Health in the Marketplace: Professionalism, Therapeutic Desires, and Medical Commodification in Late-Victorian London. Palo Alto: Society for the Promotion of Science and Scholarship, 2012.

Weissmann, Gerald. "The Atlanta Falcon and Tono-Bungay: Dietary Supplements as Subprime Drugs." FASEB Journal: Journal of the Federation of American Societies of Experimental Biology 23.5 (May 2009): 1279-82.

Wellcome, Henry. "To the Editor of the Times." Times 33167 (12 Nov. 1890): 10 (col. B). Times Digital Archive. Web. 29 Nov. 2012.

Wells, H. G. Experiment in Autobiography: Discoveries and Conclusions of a Very Ordinary Brain (Since 1866). Philadelphia: J. B. Lippincott, 1967.

—. Tono-Bungay. Ed. Brian Cheyette. 1908-09. Oxford: Oxford UP, 1996.

- Tono-Bungay: A Novel. New York: Duffield, 1922.

Young, James Harvey. The Toadstool Millionaires: a Social History of Patent Medicines in America before Federal Regulation. Princeton: Princeton UP, 1961.

Youngs, Tim. Travellers in Africa: British Travelogues, 1850-1900. Manchester: Manchester UP, 1994. 